\title{
Phenotypical Characterization of the Rat Striatal Neurons Expressing Muscarinic Receptor Genes
}

\author{
Veronique Bernard, Elisabeth Normand, and Bertrand Bloch \\ URA CNRS 1200, Laboratoire d'Histologie-Embryologie (UFR II), Universite de Bordeaux II, 33076 Bordeaux Cedex, \\ France
}

Neurons expressing the $m_{1}, m_{2}$, and $m_{4}$ muscarinic receptor genes in the adult rat striatum were identified and characterized by using several in situ hybridization and immunohistochemical procedures. Combined in situhybridization for the simultaneous detection of two mRNAs in the same section or in adjacent sections as well as in situ hybridization and immunohistochemistry on adjacent sections permitted us to identify the neurons containing $m_{1}, m_{2}$, or $m_{4}$ receptor mRNA. Our observations demonstrate that $m_{1}, m_{2}$, and $m_{4}$ receptor genes are expressed in one or several phenotypically distinct neuronal populations. The $m_{1}$ receptor gene was the most widely expressed $(85 \%$ of the striatal neurons). Most cholinergic neurons ( $80 \%$ or more) contain $\mathrm{m}_{1}$, $m_{2}$, and $m_{4}$ receptor mRNAs. Almost all the substance $P$ neurons contain $m_{1}$ and $m_{4}$ receptor mRNA. All enkephalinergic neurons contained $m_{1}$ receptor $m R N A$, but only $39 \%$ contained $m_{4}$ receptor mANA. Most somatostatin and neurotensin neurons expressed the $m_{1}$ receptor gene, but only a few (15\% and $9 \%$, respectively) contained $m_{4}$ receptor mRNA.

The present study offers anatomical evidence that $\mathrm{ACh}$ may act directly in complex ways on the main neuronal populations of the striatum through muscarinic receptors. The $m_{1}, m_{2}$, and $m_{4}$ receptors may act as autoreceptors to control $\mathrm{ACh}$ release and possibly other parameters of $\mathrm{ACh}$ neurons. On the other hand, the $m_{1}$ and $m_{4}$ receptors may act as heteroreceptors in cholinoceptive efferent neurons (enkephalin and substance $P$ neurons) and other neurons (somatostatin/neuropeptide $Y$ and neurotensin neurons). The presence of $m_{4}$ receptor mRNA in only parts of the enkephalin, somatostatin, and neurotensin neuronal populations indicates that muscarinic receptor gene expression contributes to the functional and anatomical heterogeneity of the striatum that may relate to higher order of organization, including patch-matrix compartmentalization. The wide expression of $m_{1}$ and $m_{4}$ receptor genes in the striatum sug-

\footnotetext{
Reccived Jan. 13, 1992; revised Mar. 30, 1992; accepted Apr. 7, 1992.

We thank C. Bénicourt (Société Jouveinal), W. Rostène, and S. Sabol for their generous gifts of probes for the muscarinic receptor, neurotensin, and preproenkephalin A, respectively, and R. Guennoun and $M$. Jaber for their kind help. We thank D. Theodosis for the efficient correction of the manuscript. We also thank C. Vidauporte for his photographic expertise, G. Caune for typing the manuscript, and M. Ferret and B. Proriol for technical assistance. This work was supported by grants from INSERM (Contrat Externe 900603), the Fondation de France, and the Région d'Aquitaine.

Correspondence should be addressed to V. Bernard, Laboratoire d'HistologieEmbryologie (UFR II), Université de Bordeaux II, 146 rue Léo-Saignat, 33076 Bordeaux Cedex, France.

Copyright (C) 1992 Socicty for Ncuroscicnce $0270-6474 / 92 / 123591-10 \$ 05.00 / 0$
}

gests that ACh may directly influence neurotransmitter release and synthesis in striatal efferent and intrinsic neurons. Our results imply that the specific pattern of expression of the muscarinic receptor genes mediates direct effects of ACh on activities and functions of chemically and topologically defined striatal neuronal populations. Since the expression of muscarinic receptors occurred in the three main neuronal populations of the striatum, namely $\mathrm{ACh}$, enkephalins, and substance $P$ neurons that also express dopamine receptors, it is highly probable that $\mathrm{ACh}$ and dopamine may act together at the single-cell level to influence striatal functions.

Various anatomical, electrophysiological, and pathological observations provide evidence that $\mathrm{ACh}$ plays a major role in the control of striatal function and in particular in the regulation of motor control (Hornykiewicz, 1981 ; Jabbari et al., 1989). Striatal $\mathrm{ACh}$ is released from a population of large cholinergic interneurons that establish complex synaptic contacts with dopamine terminals, originating from the substantia nigra, and with several striatal neuronal populations (Lehmann and Langer, 1982, 1983; Wainer et al., 1984; Phelps et al., 1985; Izzo and Bolam, 1988; Vuillet et al., 1992). The anatomical and physiological bases of interactions between ACh neurons and dopamine endings in the striatum have been well documented (Lehmann and Langer, 1983). ACh directly controls dopamine release in complex ways (stimulation or inhibition) depending on the striosome/matrix compartmentalization (Kemel et al., 1989; Gauchy et al., 1991). ACh and dopamine most probably interact to promote normal movements as seen from the effects of ACh antagonists or dopamine agonists that each reduce motor disorders observed in Parkinson's disease (Hornykiewicz, 1981).

Several lines of evidence also suggest that $\mathrm{ACh}$ may influence directly the activity of other striatal neurons: ACh exerts a direct excitatory influence on efferent neurons (Gauchy et al., 1992) and facilitates GABA release (Besson et al., 1987), while muscarinic receptor activation inhibits GABA release (Marchi et al., 1990; Sugita et al., 1991). Cholinergic neurons establish synaptic contact with medium-sized spiny or aspiny neurons (Wainer et al., 1984; Phelps et al., 1985; Vuillet et al., 1991), while muscarinic and nicotinic receptors have been described in the striatum (Clarke et al., 1984; Spencer et al., 1986; Levey et al., 1991; Vilaro et al., 1991). Moreover, in situ hybridization (ISH) experiments have demonstrated that several ACh receptor genes, including the $m_{1}, m_{2}$, and $m_{4}$ muscarinic receptor $\left(m_{1} R\right.$, $m_{2} R$, and $m_{4} R$ ) genes are expressed by striatal neurons with specific patterns of localization (Buckley et al., 1988; Wada et al., 1989; Weiner et al., 1990; Vilaro et al., 1991). In contrast, 
the other muscarinic receptor genes so far identified $\left(\mathrm{m}_{3} \mathrm{R}\right.$ and $\mathrm{m}_{5} \mathrm{R}$ ) are not expressed by striatal neurons (Buckley et al., 1988; Weiner et al., 1990). Taken together, these results demonstrate that certain striatal neurons are direct targets for $\mathrm{ACh}$ through the action of $m_{1} R, m, R$, and $m_{4} R$. Neuronal interactions in the striatum are complex and involve several chemically and topologically defined neuronal populations (Graybiel, 1990). This includes the ACh neurons themselves and several peptidergic neurons, most of which are also GABAergic. Of the latter, neurons producing either substance $\mathrm{P} / \mathrm{dynorphin}$ (SP/DYN) or enkephalins are efferent neurons that project to the substantia nigra and the globus pallidus, respectively. They constitute over $90 \%$ of the medium-sized spiny neurons in the striatum. Other neuronal populations include neurotensin (NT) and somatostatin/ neuropeptide Y (SRIF/NPY) neurons, which are less abundant; the latter project locally in the striatum.

In view of establishing a neuroanatomical basis for ACh actions on striatal neurons, we have developed strategies to establish which chemically defined neurons express which muscarinic receptor subtype genes. For this we used several methods involving ISH and immunohistochemistry that we have previously shown to be useful for the phenotypical characterization of neurons expressing dopamine receptor genes (Le Moine et al., 1990a,b, 1991; Le Moine and Bloch, 1991; Normand and Bloch, 1991). Our present results demonstrate that each muscarinic receptor gene known to be expressed in the striatum $\left(m_{1} R, m_{2} R\right.$, and $m_{4} R$ ) (Buckley et al., 1988; Weiner et al., 1990; Vilaro et al., 1991) displays a specific spatial expression in one or several chemically defined neuronal populations.

\section{Materials and Methods}

\section{Animals and tissue preparation}

The experiments were performed on 10 adult male rats (Wistar, Iffa Credo, L'Arbresle, France). The animals were anesthetized with pentobarbital and perfused through the heart with $1 \%$ paraformaldehyde in sodium phosphate buffer. The brains were dissected, placed in the fixative for $1 \mathrm{hr}$, left in sucrose/phosphate buffer overnight, and then frozen over liquid nitrogen (Bloch et al., 1986). Frontal serial sections $(3 \mu \mathrm{m}, 4 \mu \mathrm{m}$, or $10 \mu \mathrm{m})$ were then cut on a cryostat, collected on gelatincoated slides, and stored at $-80^{\circ} \mathrm{C}$ until use. Sections 3 and $4 \mu \mathrm{m}$ thick were indexed by pairs of adjacent sections.

\section{Probe preparation and labeling}

Synthetic oligonucleotide probes were used to detect $m_{1} R, m_{2} R, m_{4} R$, $S P, S R I F$, and NT mRNA. The sequences were chosen on the basis of the cloned sequences $\left(m_{1} R\right.$ and $m_{4} R$ : GenBank accession numbers M16406 and M16409; $\mathrm{m}_{2} \mathrm{R}$ : Gocayne et al., 1987; SP: Nawa et al., 1983; SRIF: Funckes et al., 1983; NT: Kislauskis et al., 1988). The sequences of the oligonucleotides were as follows: $m_{1} R, 5^{\prime}$-TGA CCT CTC TGA GCT GCT GCT GCT GCC ACC ACC TTT GCC TGG TGT CTC-3'; $\mathrm{m}_{2} \mathrm{R}, 5^{\prime}$-TCA CAT ACT ACA GGT CCC AAA GGC CAG TAG CCA ATC ACA GTG TAG AGG-3'; $\mathrm{m}_{4} \mathrm{R}, 5^{\prime}$-CGT TCC TTG GTG TTC TGG GTG GCA CTG CCT GAG CTG GAC TCA TTG GAA-3'; SP, 5'-CCG TTT GCC CAT CAA TCC AAA GAA CTG CTG AGG CTT GGG TCT CCG-3'; SRIF, 5' -CCA GAA GAA GTT CTT GCA GCC AGC TTT GCG TTC CCG GGG TGC CAT-3'; NT, 5'-GGC CCG GCT GCG GCA GAT CTT CTG GAG TTG GAA TAC GGT CAG CAG CGC-3'. Preproenkephalin A (PPA) mRNA (used as a marker of the enkephalin neurons) was detected either with an oligonucleotide probe (5'-GTC CAT CCA CCA CTC TGG ACG ACC TAC TCT TCT CAT GAA GCC CCC-3'; Comb et al., 1982) or with a $0.4 \mathrm{~kb}$ fragment of the cDNA cloned by Yoshikawa (Yoshikawa et al., 1984). Oligonucleotide $m_{1} R, m_{2} R, m_{4} R, S P, N T$, and PPA probes were labeled with $\alpha^{-}{ }^{35}$ S-thio-dATP (New England Nuclear; specific activity, $2 \times 10^{9} \mathrm{cpm} / \mu \mathrm{g}$ ) and SRIF probe with biotin $16 \mathrm{dUTP}$ (Enzo Biochem) by tailing procedure using terminal deoxynucleotidyl transferase (Amersham). The PPA cDNA probe was labeled by nick-trans- lation with biotin 16 dUTP (Guitteny et al., 1988; Le Moine et al., 1991).

In situ hybridization and phenotypical identification of cells expressing muscarinic receptor genes

The phenotypes of the cells expressing the muscarinic receptor genes were identified using three different procedures: (1) localization of two mRNAs on adjacent sections ( $3 \mu \mathrm{m}$ thick), (2) simultaneous visualization of two mRNAs by combined hybridization using radioactive and biotinylated probes on the same section, and (3) localization of muscarinic receptor mRNA by ISH and choline acetyltransferase by immunohistochemistry on adjacent sections ( $4 \mu \mathrm{m}$ thick).

Radioactive ISH was performed as previously described (Bernard et al., 1991; Le Moine et al., 1991). Probe [0.1 ng (m, R, SP, PPA) or 0.2 $\left.\mathrm{ng}\left(\mathrm{m}_{2} \mathrm{R}, \mathrm{m}_{4} \mathrm{R}\right)\right]$ was deposited on each slide. Sections were hybridized overnight at $40^{\circ} \mathrm{C}$, washed, and dried. Ten-micrometer-thick sections were exposed in contact with $x$-ray film (Kodak X-Omat AR5) for 3 $\left(m_{1} R\right)$ or $7 d\left(m_{2} R\right.$ or $\left.m_{4} R\right)$ and then coated with emulsion (Ilford $K 5$ ) and left in the dark during $2\left(m_{1} R\right)$ or 6-7 weeks $\left(m_{2} R, m_{4} R\right)$. They were revealed, and then either stained with toluidine blue and mounted, or processed for nonradioactive ISH (see below). Sections 3 or $4 \mu \mathrm{m}$ thick were directly coated with emulsion, exposed for $3\left(m_{1} R, S P, P P A\right)$ or 8-10 weeks $\left(m, R, m_{4} R, N T\right)$, revealed, stained with toluidine blue, and mounted.

The specificity of the ISH reaction for $m_{1} R, m_{2} R$, and $m_{4} R$ mRNA detection was controlled by addition of $m_{1} R, m_{2} R$, or $m_{4} R$ unlabeled probe or unrelated unlabeled probe $\left(D_{2}\right.$ receptor, $\left.S R I F, S P\right)$ to the hybridization medium containing labeled $m_{1} R, m_{2} R$, and $m_{4} R$ probe (data not shown). In addition, these probe sequences were shown by Weiner et al. (1990) to recognize specifically the corresponding mRNA in striatal extracts by using Northern blot procedure.

Localization of two mRNAs on adjacent sections. Each of two 3- $\mu \mathrm{m}-$ thick adjacent sections was hybridized with either a ${ }^{35} \mathrm{~S}$-labeled $m_{1} R$ or $\mathrm{m}_{4} \mathrm{R}$ probc or a ${ }^{35} \mathrm{~S}$-labcled SP, PPA, or NT probe. Sections of the same neurons were identified on paired sections after toluidine blue staining, and their labeling was compared by using a double-microscopic system coupled to an image analyzer (Histo 200, Biocom, Les Ulis, France).

Simultanecus detection of two mRNAs by combined hybridization on the same section.Sections $10 \mu \mathrm{m}$ thick were hybridized with either an $\mathrm{m}_{1} \mathrm{R}$ or an $\mathrm{m}_{4} \mathrm{R}{ }^{35} \mathrm{~S}$-labeled probe. Following autoradiography, the slides were rinsed in distilled water and then processed for nonradioactive ISH through the emulsion by using a biotinylated PPA ( $8 \mathrm{ng} / \mathrm{slide})$ or SRIF ( $4 \mathrm{ng} / \mathrm{slide}$ ) probe (for further details, see Normand and Bloch, 1991). Briefly, sections were hybridized overnight at $40^{\circ} \mathrm{C}$ and rinsed in saline-sodium citrate. After incubation ( $1 \mathrm{hr}$ ) with streptavidin alkaline phosphatase (1:100; Dakopatts), the signal was revealed with nitroblue tetrazolium-bromochloroindolyl phosphate (GIBCO/Bethesda Research Laboratories). Slides were then rinsed and mounted in Aquamount without counterstaining.

Localization of muscarinic receptor $m R N A$ and choline acetyltransferase immunoreactivity on adjacent sections. Each of two $4-\mu \mathrm{m}$-thick adjacent sections was hybridized with either an $m_{1} R, m_{2} R$, or $m_{4} R{ }^{35} S$ labeled probe as described above or processed for immunohistochemical detection of choline acetyltransferase (ChAT), a specific marker of cholinergic neurons (Kuhar, 1976). ChAT was detected using a monoclonal antibody raised against rat ChAT (Boehringer-Mannheim). Slides were incubated in phosphate-buffered saline (PBS) pH 7.4 with $1 \%$ normal goat serum (NGS) and $0.3 \%$ Triton X-100 (TX-100) for $1 \mathrm{hr}$ at $20^{\circ} \mathrm{C}$ and then with ChAT antibody $(1 \mu \mathrm{g} / \mathrm{ml}$ in PBS, pH 7.4, $1 \% \mathrm{NGS}, 0.3 \%$ TX-100) for $48 \mathrm{hr}$ at $4^{\circ} \mathrm{C}$. Immunoreactivity was revealed with an immunoperoxidase procedure using anti-rat IgG (Dakopatts; 1:200) and rat peroxidase-antiperoxidase (Sternberger-Meyer; 1:200). The slides were then treated with diaminobenzidine (Sigma; $0.05 \%$ in Tris buffer sodium, $\mathrm{pH} 7.6$ ) and the staining intensified with $2 \%$ osmium tetroxide. Sections were then dehydrated and mounted. The image analyzer was used to identify neurons that were both immunolabeled and showed ISH signal on adjacent sections.

\section{Results}

Topography of the neurons expressing $m_{1} R, m_{2} R$, and $m_{4} R$ genes

Analysis of $\mathrm{x}$-ray films after ISH provided an overall view of the localization of $m_{1} R$ or $m_{4} R$ mRNA and demonstrated an homogeneous labeling in the caudate-putamen, accumbens nu- 

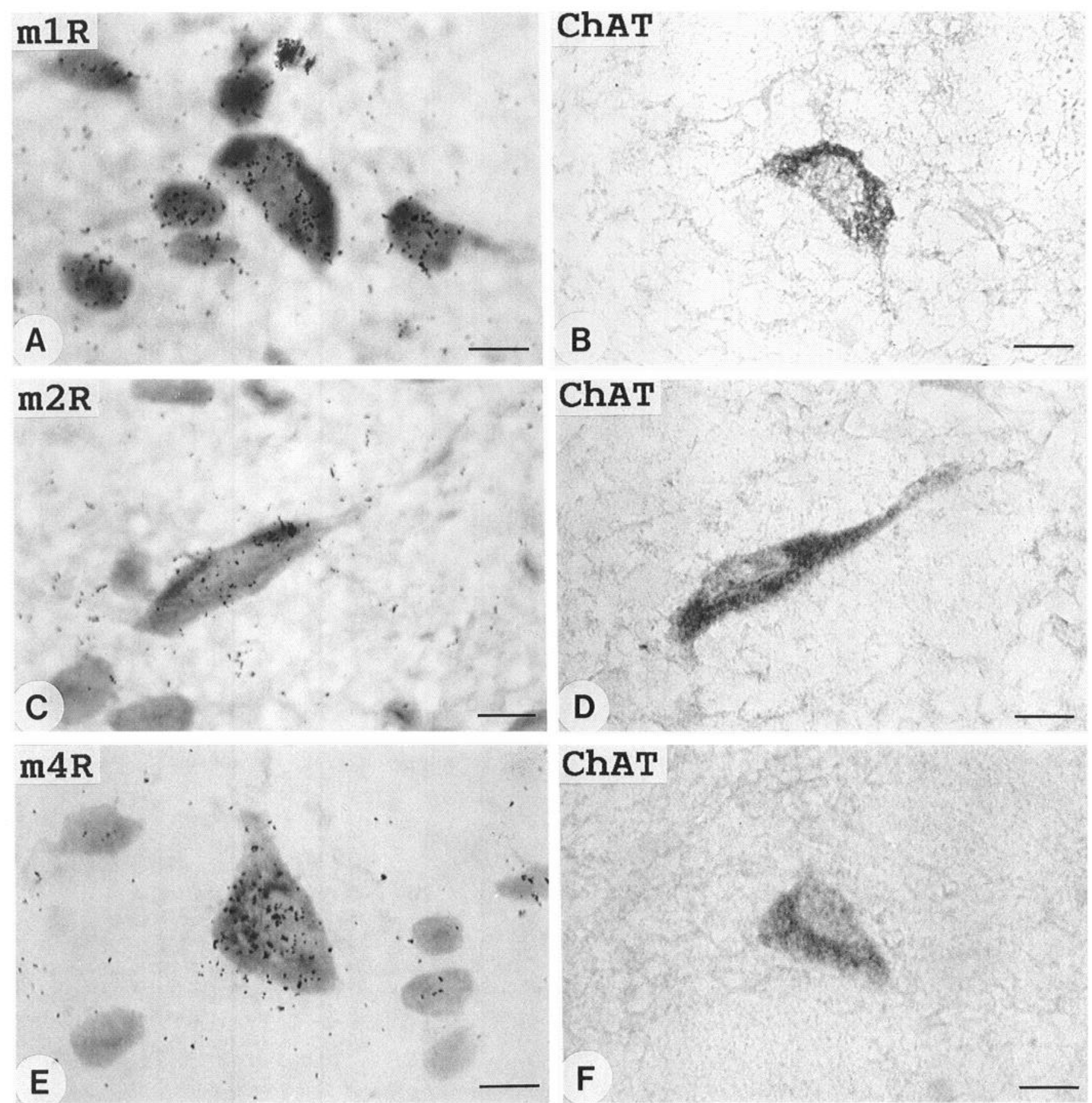

Figure 1. Characterization of the large-sized neurons containing muscarinic receptor mRNA. Adjacent 4- $\mu$ m-thick sections were hybridized with muscarinic receptor probes $(A, C, E)$ or processed for immunohistochemical detection of ChAT $(B, D, F)$. Large-sized neurons displaying labeling for $\mathrm{m}_{1} \mathrm{R}(A), \mathrm{m}_{2} \mathrm{R}(C)$, or $\mathrm{m}_{4} \mathrm{R}(E)$ mRNA also contain ChAT immunoreactivity. Scale bars, $10 \mu \mathrm{m}$.

cleus, olfactory tubercle, islands of Calleja, cortex, and septum as described previously (Buckley et al., 1988; Weiner et al., 1990; Vilaro et al., 1991). Because of the limited resolution provided by $\mathrm{x}$-ray films, we could not detect the signal for $\mathrm{m}_{2} \mathrm{R}$ mRNA at this macroscopic level.

The microautoradiographic analysis demonstrated clusters of labeled cells throughout the striatum, the cortex, and the septum with the $m_{1} R$ and the $m_{4} R$ probe. Our counts estimated that $85 \%$ of the striatal neurons demonstrated labeling with the $m_{1} R$ probe and $61 \%$ with the $m_{4} R$ probe. Labeling was present over large-sized (20-30 $\mu \mathrm{m}$ in diameter) (Fig. 1) and medium-sized neurons (10-15 $\mu \mathrm{m}$ in diameter) (Figs. 2, 3). With the $\mathrm{m}_{1} \mathrm{R}$ probe, labeling was also noted in cells bordering the lateral ventricle and the choroid plexus cells. The $m_{2} R$ probe provided labeling restricted to the large-sized neurons in the striatum (Fig. 1).

Identity of the striatal neurons expressing muscarinic receptor genes

In order to establish which muscarinic receptor mRNA was present in chemically identified neuronal populations, we analyzed paired 3- or 4- $\mu \mathrm{m}$-thick adjacent sections, as well as 10- 

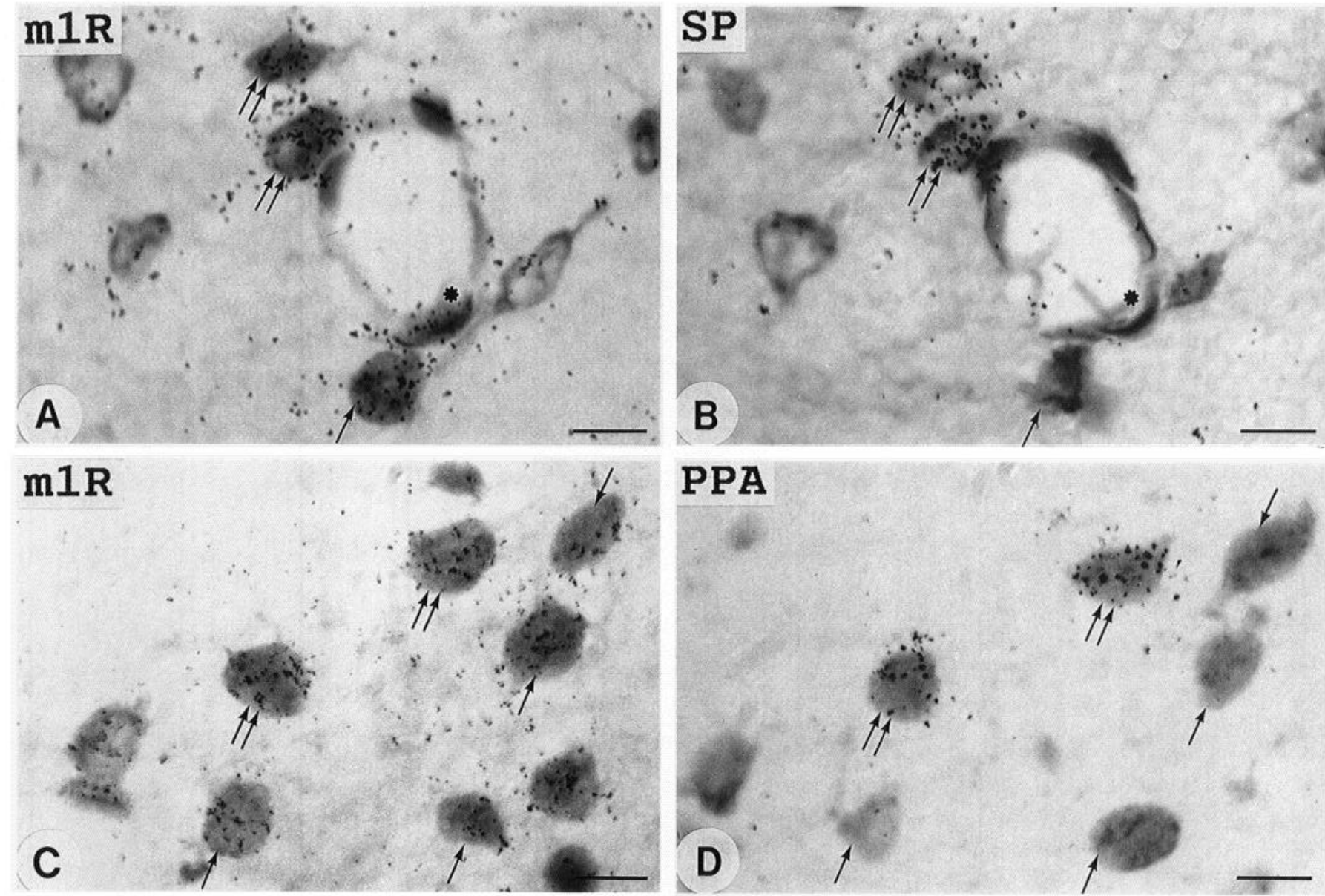
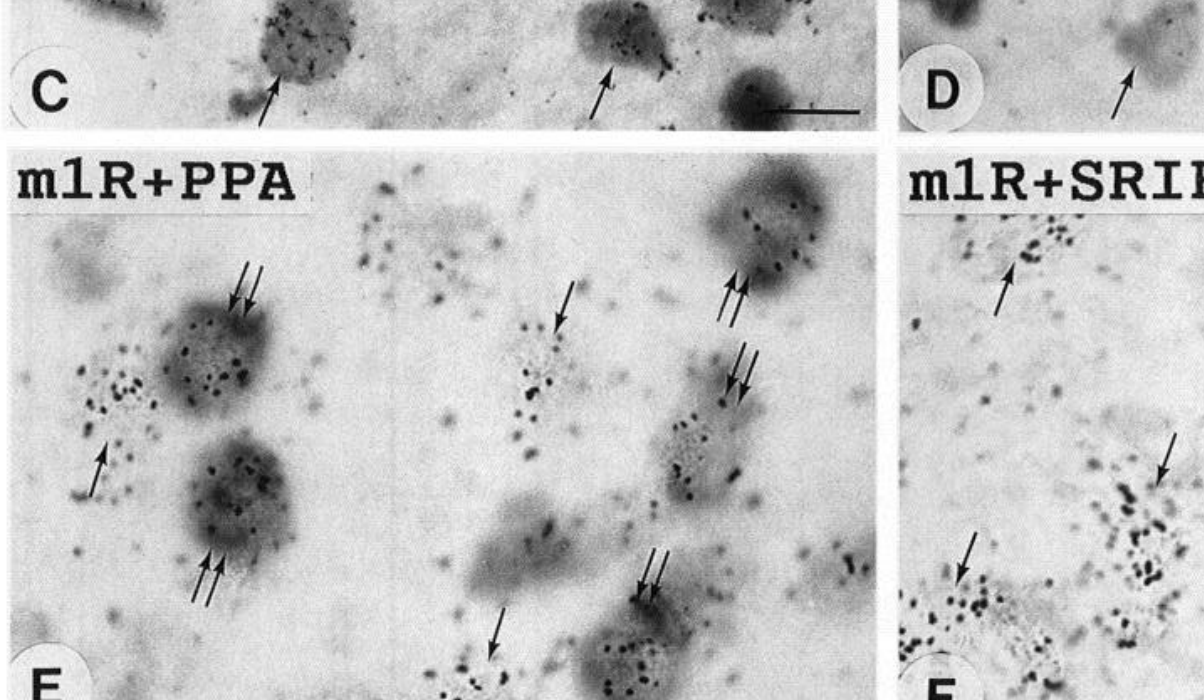

\section{m1R+SRIF}
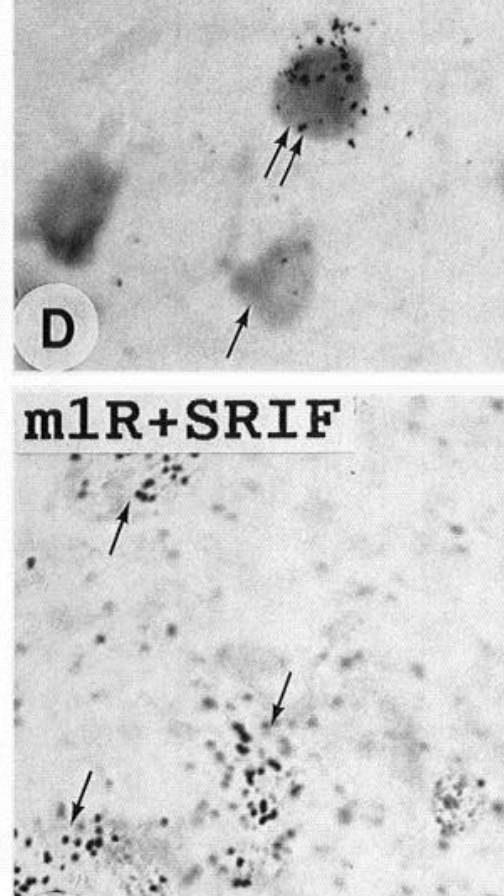

$F \leadsto$

\section{NT}

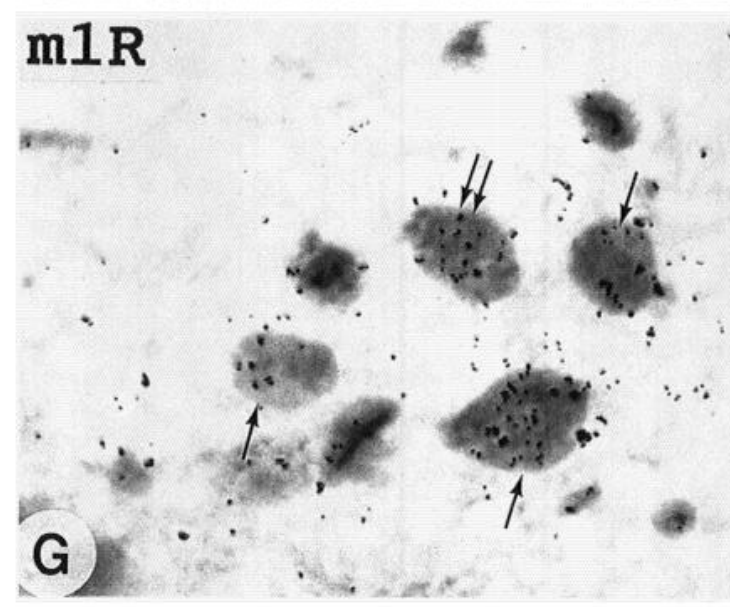

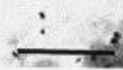

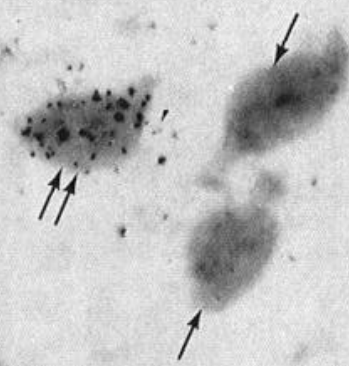

해영

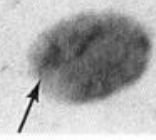

$3.2 x^{3}$

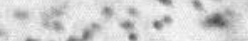

$\because 345 ; 5$

$7+1^{2}+5 ?$

$x^{2}+12$

3.20

if: 24

4 
$\mu \mathrm{m}$-thick sections that had been hybridized for the simultaneous detection of two mRNAs. We were thus able to analyze a total of 800 PPA and SP neurons, over 300 SRIF neurons and ChATpositive neurons, and over $40 \mathrm{NT}$ neurons (the latter being very scarce).

As expected, the large-sized neurons were ChAT immunoreactive. Most of them contained label for each of the muscarinic probes tested: $88 \%$ for $m_{1} R, 80 \%$ for $m_{2} R$, and $83 \%$ for $m_{4} R$ (Fig. 1).

Comparative analysis of the $3-\mu \mathrm{m}$-thick adjacent sections labeled with the SP probe or with the $m_{1} R$ or $m_{4} R$ probes demonstrated that nearly all SP striatal neurons contained $\mathrm{m}_{1} \mathrm{R}$ and $\mathrm{m}_{4} \mathrm{R}$ mRNA (m $\left.\mathrm{R}, 95 \% ; \mathrm{m}_{4} \mathrm{R}, 94 \%\right)$ (Figs. $\left.2 A, B ; 3 A, B\right)$. A similar analysis indicated that nearly all (95\%) neurons containing PPA mRNA also contained $\mathrm{m}_{1} \mathrm{R}$ mRNA (Fig. $2 C, D$ ). In contrast, only $39 \%$ of PPA neurons contained $m_{4} R$ mRNA (Fig. $3 C, D)$. The simultaneous detection of PPA $\mathrm{mRNA}$ and $\mathrm{m}_{1} \mathrm{R}$ or $\mathrm{m}_{4} \mathrm{R}$ mRNA on the same $10 \mu \mathrm{m}$ sections confirmed that the $m_{1} R$ signal was present in all PPA neurons, while $m_{4} R$ mRNA was detectable in only a portion of this population (Figs. $2 E$, $3 E$ ). Analysis of adjacent sections showed that most NT neurons $(86 \%)$ also showed labeling with the $\mathrm{m}_{1} \mathrm{R}$ probe (Fig. $\left.2 G, H\right)$. In contrast, only $9 \%$ of NT cells contained $\mathrm{m}_{4} \mathrm{R}$ mRNA (Fig. $3 G, H$ ). Double ISH with a biotinylated SRIF probe and a radioactive $m_{1} R$ or $m_{4} R$ probe on same $10-\mu \mathrm{m}$-thick sections demonstrated that most SRIF neurons (93\%) showed labeling with the $m_{1} R$ probe (Fig. $2 F$ ), whereas only $15 \%$ were labeled with the $m_{4} R$ probe (Fig. $3 F$ ).

\section{Discussion}

The present observations provide evidence that several chemically defined neuronal populations or subpopulations in the striatum contain one or several muscarinic receptor mRNA isotypes (Fig. 4). This implies that such neurons produce the corresponding receptors and are direct targets for ACh released in the striatum. Our data are thus in agreement with earlier anatomical and electrophysiological investigations (Phelps et al., 1985; Izzo and Bolam, 1988; Kemel et al., 1989; Dawson et al., 1990; Weiner et al., 1990; Gauchy et al., 1991; Vuillet et al., 1992; Wainer et al., 1984), including the recent demonstration of immunoreactivity for $m_{1} R, m, R$, and $m_{4} R$ subtypes in the rat striatum (Levey et al., 1991). Our results demonstrate, moreover, that the neuronal populations involved in the production of the muscarinic receptors include ACh neurons themselves, where muscarinic receptors may act as autoreceptors. In the other neuronal populations, which may be efferent neurons and interneurons, muscarinic receptors may act as postsynaptic heteroreceptors. Our observations also reveal a heterogeneity of muscarinic receptor gene expression in the striatum and indicate that each neuronal population has its own specific pattern of expression.

\section{Muscarinic receptor gene expression by ACh neurons}

Our results provide clear morphological evidence that most cholinergic neurons in the striatum express three muscarinic receptor genes, $m_{1} R, m_{2} R$, and $m_{4} R$. They are thus in agreement with pharmacological evidence demonstrating presynaptic inhibition of $\mathrm{ACh}$ release by autoreceptors (James and Cubeddu, 1987; Lapchack et al., 1989; Dolezal and Wecker, 1990) and with anatomical evidence showing cholinergic terminals in contact with cholinergic cell bodies and dendrites (Phelps et al., 1985). Also, it has been noted that destruction of cholinergic neurons with the AF64A neurotoxin provokes the loss of presynaptic cholinergic markers, including autoreceptors (Dawson et al., 1990). Several experiments suggest that the autoreceptors are of the pharmacological $\mathbf{M}_{2}$ subtype (Lapchack et al., 1989) that would be encoded by $\mathrm{m}_{2} \mathrm{~K}$ mRNA isotypes (Buckley et al., 1989); these data corroborate our observations, and those of Wcincr ct al. (1990) and Levey ct al. (1991) of $m_{2} R$ mRNA and $m_{2} R$ immunoreactivity in certain large-sized striatal neurons, which are most probably cholinergic. Nevertheless, Weiner et al. (1990) found very little signal for $m_{1} R$ and $m_{4} R$ mRNA in large-sized neurons. However, we saw an intense signal for $m_{1} R$ and $m_{4} R$ mRNA in most cholinergic neurons. Since the probes used were identical in the two studies, the discrepancy may be due to a greater sensitivity provided by our ISH procedure. In any case, we found that reactivity to $m_{1} R$ and $m_{4} R$ probes was always intense and reliable, and together with our appropriate controls for specificity, our data provide strong evidence for the simultaneous expression of three autoreceptor genes in striatal cholinergic neurons. Nevertheless, a certain number of these neurons $(12 \%, 17 \%$, or $20 \%)$ did not display, respectively, $m_{1} R$, $m_{2} R$, or $m_{4} R$ signal. This may mean that our ISH procedure was not able to detect low mRNA levels in certain neurons. Alternatively, such data may reflect a real absence of muscarinic receptor gene expression in a subpopulation of striatal $\mathrm{ACh}$ neurons.

In spite of these reservations, our results clearly indicate that most ACh neurons in the striatum are under the control of $\mathrm{ACh}$ via three muscarinic receptors. Each muscarinic receptor isotype has a specific pharmacological profile and has been shown to interact with distinct second messengers. The $m_{1} R$ is preferentially linked to phospholipase $C$ through an unknown $G$-protein, while $m_{2} R$ and $m_{4} R$ act preferentially on adenylate cyclase through $\mathrm{G}_{i}$ protein (Richards, 1991). While one of these muscarinic receptors $\left(m_{2} R\right)$ is most probably involved in the inhibition of ACh release (Lapchak et al., 1989), the presence of these three distinct receptor isotypes in the same neurons suggests that they may contribute to other functions related to the activity of the cholinergic neurons, including choline uptake and ACh biosynthesis.

In view of the diversity of neuronal interactions in the striatum, it is highly probable that its cholinergic neurons are under complex neuronal influences. Indeed, as pointed out earlier, the ACh neurons also express dopamine receptor genes (Le Moine et al., 1990b, 1991), and in particular the $D_{2}$ receptor $\left(D_{1}\right.$ receptor is found only in a small subpopulation). Recent evidence suggests that the $\mathrm{D}_{2}$ and muscarinic receptors could interact in cholinergic neurons to inhibit ACh release by controlling the opening of the same $\mathrm{K}^{+}$channel (Drukarch et al., 1990). Thus,

\footnotetext{
Figure 2. Characterization of the striatal neurons containing $\mathrm{m}_{1} \mathrm{R}$ mRNA. $A-D, G$, and $H$, Comparison of 3- $\mu$ m-thick adjacent sections hybridized with either an $\mathrm{m}_{1} \mathrm{R}$ probe $(A, C, G)$ or an SP $(B)$, PPA $(D)$, or NT $(H)$ probe. Neurons were counterstained with toluidine blue. The neurons labeled with the SP, PPA, or NT probe also show labeling for the $\mathrm{m}_{1} \mathrm{R}$ probe (double arrows). In each set of sections, some neurons show labeling only for $\mathrm{m}_{1} \mathrm{R}$ mRNA (single arrows). $E$ and $F$, Combined hybridization with ${ }^{35}$ S-labeled $\mathrm{m}_{1} \mathrm{R}$ probe and PPA $(E)$ or SRIF $(F)$ biotinylated probe on the same section. No counterstaining is seen. The $m_{1} R$ mRNA is detected by silver grains; the PPA and SRIF mRNA, by a colored reaction. PPA and SRIF neurons contain $m_{1} R$ mRNA (double arrows). Some neurons contain only $m_{1} R$ mRNA (single arrows). ${ }^{*}$, blood vessel. Scale bars, $10 \mu m$.
} 


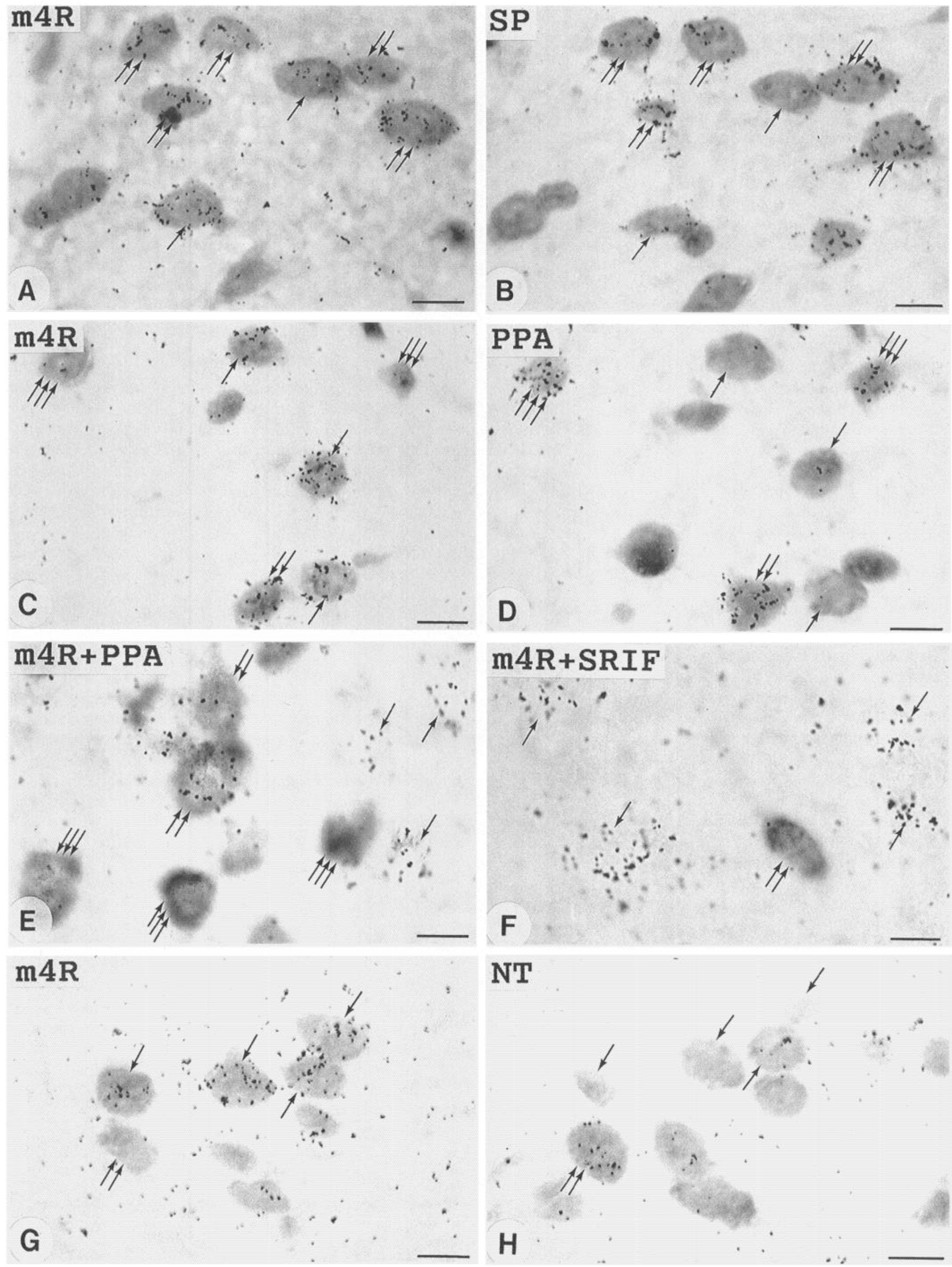


cholinergic neurons appear as likely candidates for direct dopamine-ACh interactions in the striatum. In addition, cholinergic neurons also ex press SP receptors (Elde et al., 1990; Gerfen, 1991). In contrast, they have no detectable NT or $A_{2}$ adenosine receptor mRNA (Elde et al., 1990; Schiffmann et al., 1991). It is probable that further investigations will demonstrate other neurotransmitter receptors in these neurons, especially those for glutamate since glutamate has been shown to stimulate directly ACh release from the striatum through NMDA receptors (Scatton and Lehmann, 1982).

\section{Medium-sized substance $P$ and enkephalin efferent neurons}

The striatum contains two main efferent neuronal populations: the striatonigral neurons producing essentially SP, DYN, and GABA, and the striatopallidal neurons producing enkephalins and GABA (Graybiel, 1990). We have shown here that $m_{1} R$ and $m_{4} R$ are expressed with specific patterns in both SP and enkephalin neurons; the $m_{1} R$ gene appeared expressed in nearly all the efferent neurons. These results thus provide evidence that ACh controls directly the activity of the striatal efferent neurons. They confirm and extend previous observations suggesting a direct action of ACh on such neurons. For example, cholinergic terminals contact medium-sized striatonigral neurons (Izzo and Bolam, 1988) and ACh stimulates the release of enkephalins and GABA (Hong et al., 1980; Besson et al., 1987); muscarinic agonists inhibit the release of GABA in the striatum (Marchi et al., 1990; Sugita et al., 1991). In addition, other recent studies have also visualized $m_{1} R$ and $m_{4} R$ mRNA in medium-sized neurons (Weiner et al., 1990) and muscarinic binding sites on SP cell bodies (Ariano and Kenny, 1989). Interestingly, while $m_{1} R$ and $m_{4} R$ mRNAs are expressed in the same efferent neurons, recent immunocytochemical evidence revealed distinct compartmentalization for the corresponding proteins. An $m_{4} R$ immunoreactivity was found in the striatum and in terminals in the substantia nigra, while $m_{1} R$ appeared restricted to the striatum, most probably on cell bodies and dendrites (Levey et al., 1991).

Indeed, as shown here, most if not all SP neurons appear under the double control of the $m_{1} R$ and $m_{4} R$. We and others have recently shown that these neurons also express the $D_{1}$ dopamine receptor gene (Gerfen et al., 1990; Le Moine et al., 1991), indicating that SP neurons are under at least dopaminergic and cholinergic control. ACh is known to exert a direct and indirect inhibitory control on the release of dopamine through muscarinic receptors (Kemel et al., 1989; Gauchy et al., 1991). Direct control may occur through muscarinic receptors located on dopamine terminals $\left(m_{5} R\right.$ according to Weiner et al., 1990), whereas indirect control may derive from DYN neurons bearing muscarinic receptors (Gauchy et al., 1991). Since DYN and SP are colocalized in the same neurons (Reiner and Anderson, 1990), our results suggest that the indirect in-

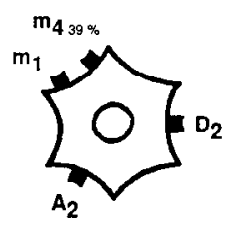

ENKEPHALINS

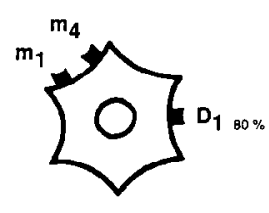

SUBSTANCE $P$

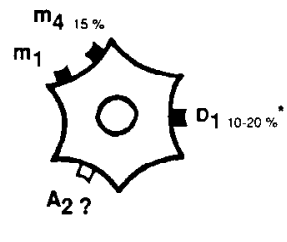

SOMATOSTATIN

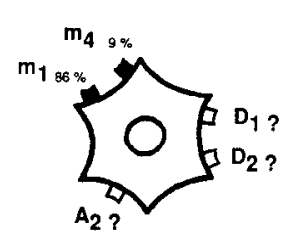

NEUROTENSIN

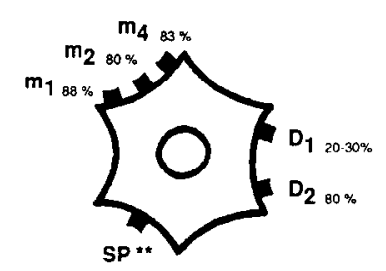

ACETYLCHOLINE
Figure 4. Schematic representation of neurotransmitter receptor gene expression in chemically identified striatal neurons. The diagram summarizes observations from the present and earlier studies (Elde et al., 1990; Le Moine et al., 1990a,b, 1991; Weiner et al., 1990; Gerfen, 1991; Schiffmann et al., 1991). The presence of a receptor on a neuron, without a percentage, indicates that over $90 \%$ of the neurons in the population contain the receptor mRNA; for receptors under $90 \%$, percentages indicate the proportion of neurons expressing the gene; the absence of a receptor symbol indicates that the neuronal population does not express the gene. NT receptor is not mentioned since NT receptor gene expression is not detectable in the striatum (Elde et al., 1990). Open and ? symbols indicate that no information is available at the moment for the corresponding gene in the given neuronal population. $m_{t}, m_{2}, m_{4}$, muscarinic receptors; $D, D$, dopamine receptors; $A$, adenosine receptor; $S P$, substance P receptor $\left(^{*}\right.$, from Le Moine et al., 1991; C. Le Moine et al., unpublished observations; ${ }^{* *}$, from Gerfen (1991), percentage of labeled neurons not mentioned in the publication).

hibitory control of dopamine release occurs through the $m_{1} R$ and/or the $m_{4} R$ located on the striatonigral neurons. Also, the presence of SP receptors on cholinergic neurons (Gerfen, 1991) suggests that $\mathrm{ACh}$, as well the $\mathrm{SP}$ released from collaterals of striatonigral neurons, may contribute to reciprocal synaptic interactions between the two neuronal populations.

Nearly all striatopallidal enkephalinergic neurons express the $m_{1} R$ gene, but only $39 \%$ contain detectable levels of $m_{1} R$ mRNA. While we cannot exclude that the sensitivity of our procedures underestimated the percentage of neurons expressing the $m_{4} R$ gene, the presence of intensely $m_{4} R$-reactive neurons together with unlabeled ones in the same sections (even after long exposure times) strongly suggests the existence of two subpopulations with respect to $m_{4} R$ gene expression. Weiner et al. (1990) also observed that only $37 \%$ of the neurons containing $D_{2}$ receptor mRNA [which we have shown to be enkephalinergic (Le Moine et al., 1990a)] contained $\mathrm{m}_{4} \mathrm{R}$ mRNA. If neurons unlabeled with the $m_{4} R$ probe in the present study do express the

$\leftarrow$

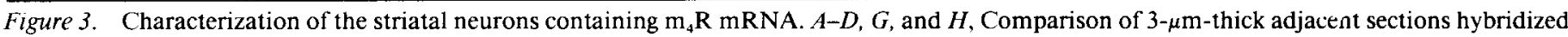

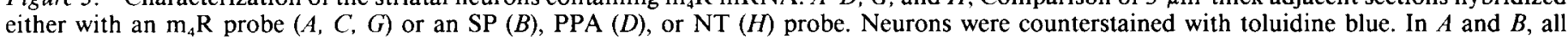

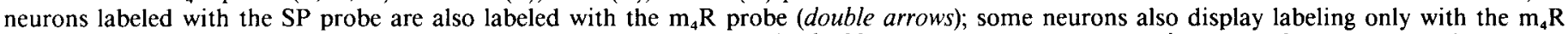

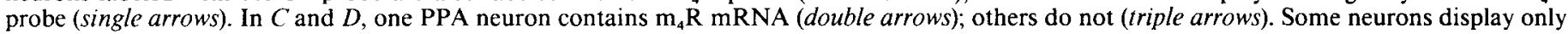

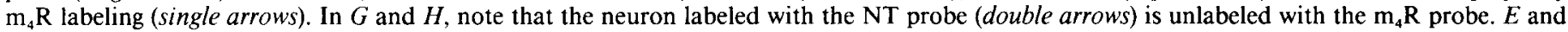

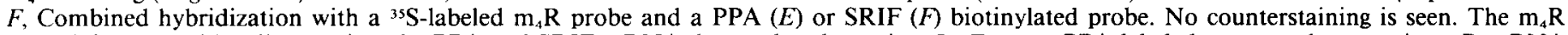

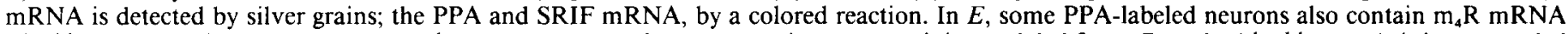

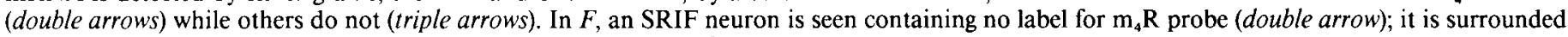
by several neurons showing strong labeling for $\mathrm{m}_{4} \mathrm{R}$ mRNA (single arrows). Scale bars, $10 \mu$. 
$m_{4} R$ gene, it would be at a level far below that observed in reactive neurons. In any case, our observations demonstrate heterogeneity among enkephalinergic neurons with respect to muscarinic control. It is known that cholinergic markers are differentially distributed in striosomes and matrix. In particular, $M_{1}$ binding sites (probably encoded by $m_{1} R$ and $m_{4} R$ gene) are heterogeneously distributed in the human and cat striatum (Nastuk and Graybiel, 1985; Lowenstein et al., 1990). Since neurons expressing the $m_{1} R$ gene are evenly distributed in the striatum, it is important to see whether the existence of two enkephalinergic neuronal populations with respect to $m_{4} R$ gene expression could relate to striosome-matrix organization. Mapping of these two cell subpopulations together with striosome-matrix markers may help to answer this question. Since muscarinic binding sites were absent in the globus pallidus (Spencer at al., 1986), one would expect that most muscarinic receptors in enkephalinergic neurons are in cell bodies, dendrites, and collaterals permitting interaction with $\mathrm{ACh}$ released in the striatum.

\section{Somatostatin and neurotensin neurons}

Since the $m_{1} R$ gene is expressed in most SRIF and NT neurons, as it is in SP and enkephalinergic neurons, the $m_{1} R$ appears to be the main actor in muscarinic control of these neurons. In contrast, $m_{4} R$ may play only a minor role since $m_{4} R$ gene expression was present in only limited subpopulations $(15 \%$ for SRIF neurons, $9 \%$ for NT neurons). That SRIF neurons are under ACh control is supported by ultrastructural studies demonstrating synaptic contacts between cholinergic and NPY neurons (Vuillet et al., 1992), known to coexpress SRIF (Smith and Parent, 1986). Also, muscarinic binding sites have been seen over SRIF cell bodies (Ariano and Kenny, 1989). Vuillet et al. (1992) have recently provided anatomical evidence for reciprocal interactions between $\mathrm{ACh}$ and NPY/SRIF interneurons, which may mediate cholinergic effects in the striatum. If so, it remains to be shown that $\mathrm{ACh}$ neurons also express the recently cloned NPY receptor (Rimland et al., 1991). The evidence for reciprocal interactions between $\mathrm{ACh}$ and NT neurons is weaker: muscarinic antagonists decrease NT levels in the striatum (Frey et al., 1988), but ACh neurons do not express the NT receptor (Elde et al., 1990).

\section{Conclusion}

Our results demonstrate that each identified neuronal population in the striatum is under the direct control of the $\mathrm{ACh}$ neurons through the expression of muscarinic receptors, and in particular the $m_{1} R$. They also show that three major neuronal populations in the striatum, namely, ACh, enkephalins, and SP/ DYN neurons, simultaneously express muscarinic and dopamine receptors (Fig. 4), thus strongly suggesting that $\mathrm{ACh}-$ dopamine interactions may occur at the single-cell level in interneurons and efferent neurons of the striatum. We found that certain of these populations were heterogeneous with respect to the expression of certain muscarinic receptors, especially $m_{4} R$. Also, since only $85 \%$ of the medium-sized neurons contain $m_{1} R$ (Weiner et al., 1990), it is probable that a small proportion of unidentified striatal neurons escape muscarinic control. Nevertheless, it is now clear that nicotinic receptor genes are also expressed in striatal neurons, especially $\alpha_{3}$ and $\beta_{2}$ subunits, with a restricted and heterogeneous pattern (Wada et al., 1989). The experimental strategies we have developed may now prove useful to establish which neuronal populations express these nicotinic receptor gene subtypes. Finally, they may also allow vi- sualization of potential ACh receptor gene expression by glial cells, as has been suggested (Repke and Maderspach, 1982), in this area of the CNS.

Many investigations have studied the physiological and eventually pathological basis of $\mathrm{ACh}$ actions and dysfunctions in the striatum, especially during extrapyramidal movement disorders (Albin et al., 1989). Indeed, the action of muscarinic antagonists in controlling movement disorders offers strong evidence for the physiological relevance of $\mathrm{ACh}$ activities in the striatum. Indeed, cholinergic neurons appear central in striatal circuitry: they are targets for several influences, and in particular corticostriatal (glutamatergic) (Scatton and Lehmann, 1982) and nigrostriatal (dopaminergic) (Dawson et al., 1990; Le Moine et al., 1990b) terminals; they provide inputs to striatal neurons and especially to the GABAergic efferent neurons that are major actors in striatal functions. Surprisingly, although many studies have concentrated on the cellular and molecular mechanisms involved in the control of dopaminoceptive striatal neurons by dopamine, comparatively less attention has been given to action of $\mathrm{ACh}$. It is clear today that dopamine inputs regulate in complex ways the synthesis and release of various neurotransmitters produced by dopaminoceptive efferent neurons, including GABA, SP, and enkephalins (Tang et al., 1983; Young et al., 1986; Normand et al., 1987; Morris et al., 1988; Gerfen et al., 1990, 1991). Since most striatal neurons express muscarinic receptor subtypes, and since the heterogeneous distribution of muscarinic receptor mRNAs suggests differential regulation of specific subpopulations, one must expect that $\mathrm{ACh}$ also regulates the synthesis and release of several neurotransmitters in the striatum. It is already known that ACh stimulates GABA and enkephalin release (Hong et al., 1980; Besson et al., 1987). On the basis of our results, experimental conditions interacting with ACh neurotransmission must now help to provide a better understanding of molecular and cellular sites of action of $\mathrm{ACh}$ in the striatum.

\section{References}

Albin RL, Young AB, Penney JB (1989) The functional anatomy of hasal ganglia disorders. Trends Neurosci 12:366-375.

Ariano MA, Kenny SL (1989) Striatal muscarinic receptors are associated with substance $P$ and somatostatin containing neurons. Brain Res 497:51-58.

Bernard V, Le Moine C, Bloch B (1991) Striatal neurons express increased level of dopamine $\mathrm{D}_{2}$ receptor $\mathrm{mRNA}$ in response to haloperidol treatment: a quantitative in situ hybridization study. Neuroscience $45: 117-126$.

Besson MJ, Girault JA, Spampinato U, Desban R, Gauchy C, Kemel ML, Glowinski J (1987) Modulation by dopamine and dopaminergic agonists of ${ }^{3} \mathrm{H}-\mathrm{GABA}$ released from striatal and nigro-thalamic GABAergic neurons. In: Neurotransmitter interactions in the basal ganglia (Sandler M, Feuerstein C, Scatton B, eds), pp 143-153. New York: Raven.

Bloch B, Popovici T, Le Guellec D, Normand E, Chouham S, Guitteny AF, Böhlen P (1986) In situ hybridization histochemistry for the analysis of gene expression in the endocrine and central nervous system tissues: a three year experience. J Neurosci Res 16:183-200.

Buckley NJ, Bonner TI, Brann MR (1988) Localization of a family of muscarinic receptor mRNAs in rat brain. J Neurosci 8:4646-4652.

Buckley NJ, Bonner TI, Bucklcy CM, Brann MR (1989) Antagonist binding properties of five cloned muscarinic receptors expressed in CHO-K1 cells. Mol Pharmacol 35:469-476.

Clarke PBS, Pert CB, Pert A (1984) Autoradiographic distribution of nicotine receptors in rat brain. Brain Res 323:390-395.

Comb M, Seeburg PH, Adelman J, Eiden L, Herbert E (1982) Primary structure of the human met and leu-enkephalin precursor and its mRNA. Nature 295:663-666.

Dawson VL, Dawson TM, Wamsley JK (1990) Muscarinic and do- 
paminergic receptor subtypes on striatal cholinergic interneurons. Brain Res Bull 25:903-912.

Dolezal V, Wecker L (1990) Muscarinic receptor blockade increases basal acetylcholine release from striatal slices. J Pharmacol Exp Ther 252:739-743

Drukarch B, Schepens E, Stoof JC (1990) Muscarinic receptor activation attenuates $D_{2}$ dopamine receptor mediated inhibition of acetylcholine release in rat striatum: indications for a common signal transduction pathway. Neuroscience 37:1-9.

Elde R, Schalling M, Ceccatelli S, Nakanishi S, Hökfelt T (1990) Localization of neuropeptide receptor mRNA in rat brain: initial observations using probes for neurotensin and substance $\mathrm{P}$ receptors. Neurosci Lett 120:134-138.

Frcy P, Lis M, Coward DM (1988) Neurotensin concentrations in rat striatum and nucleus accumbens: further studies of their regulation. Neurochem Int 12:33-38.

Funckes CL, Minth CD, Deschenes R, Magazin M, Tavianini MA, Sheets M, Collier K, Weith HL, Aron DC, Aroos BA, Dixon JE (1983) Cloning and characterization of a mRNA encoding rat preprosomatostatin. J Biol Chem 258:8781-8787.

Gauchy C, Desban M, Krebs MO, Glowinski J, Kemel ML (1991) Role of dynorphin-containing neurons in the presynaptic inhibitory control of the acetylcholine-evoked release of dopamine in the striosomes and the matrix of the cat caudate nucleus. Neuroscience 41: $449-458$.

Gerfen CR (1991) Substance P (neurokinin-1) receptor mRNA is selectively expressed in cholinergic neurons in the striatum and basal forcbrain. Brain Res 556:165-170.

Gerfen CR, Engber TM, Mahan LC, Susel Z, Chase TN, Monsma FJ, Sibley DR (1990) $\mathrm{D}_{1}$ and $\mathrm{D}_{2}$ dopamine receptor-regulated gene expression of striatonigral and striatopallidal neurons. Science 250:14291432.

Gerfen CR, McGinty JF, Young WS III (1991) Dopamine differentially regulates dynorphin, substance $P$, and enkephalin expression in striatal neurons: in situ hybridization histochemical analysis. J Neurosci 11:1016-1031.

Gocayne J, Robinson DA, Fitzgerald MG, Chung FZ, Kerlavage AR, Lentes KU, Lai J, Wang CD, Fraser CM, Venter JC (1987) Primary structure of rat cardiac $\beta_{2}$-adrenergic and muscarinic cholinergic receptors obtained by automated DNA sequence analysis: further evidence for a multigene family. Proc Natl Acad Sci USA 84:82968300.

Graybiel AM (1990) Neurotransmitters and neuromodulators in the basal ganglia. Trends Neurosci 13:244-253.

Guitteny AF, Fouque B, Mougin C, Teoule R, Bloch B (1988) Histological detection of messenger RNAs with biotinylated synthetic oligonucleotide probes. J Histochem Cytochem 36:563-571.

Hong JS, Yang HYT, Gillin JC, Costa E (1980) Effects of long-term administration of antipsychotic drugs on enkephalinergic neurons. Adv Biochem Psychopharmacol 24:223-232.

Hornykiewicz O (1981) Brain neurotransmitter changes in Parkinson's disease. In: Movement disorders (Marsden DC, Fahn S, eds), pp 4158. Boston: Butterworth.

lzzo PN, Bolam JP (1988) Cholinergic synaptic input to different parts of spiny striatonigral neurons in the rat. J Comp Neurol 269:219234.

Jabbari B, Scherokman B, Gunderson CH, Rosenberg ML, Miller J (1989) Treatment of movement disorders with trihexyphenidyl. Mov Disord 4:202-212.

James MK, Cubeddu LX (1987) Pharmacologic characterization and functional role of muscarinic autoreceptors in the rabbit striatum. $\mathrm{J}$ Pharmacol Exp Ther 240:203-215.

Kemel ML, Desban M, Glowinski J, Gauchy C (1989) Distinct presynaptic control of dopamine release in striosomal and matrix areas of the cat caudate nucleus. Proc Natl Acad Sci USA 86:9006-9010.

Kislauskis E, Bullock B, McNeil S, Dobner PR (1988) The rat gene encoding neurotensin and neuromedin N. J Biol Chem 263:49634968.

Kuhar MJ (1976) The anatomy of cholinergic neurons. In: Biology of cholinergic function (Goldberg AM, Hanin I, eds), pp 2-27. New York: Raven.

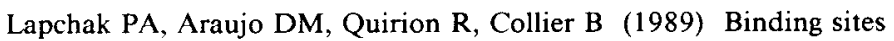
for [ $\left.{ }^{3} \mathrm{H}\right] \mathrm{AF}-\mathrm{DX} 116$ and effect of AF-DX 116 on endogenous acetylcholine release from rat brain slices. Brain Res 496:285-294.

Lehmann J, Langer SZ (1982) Muscarinic receptors on dopamine terminals in the cat caudate nucleus: neuromodulation of $\left[{ }^{3} \mathrm{H}\right] \mathrm{dopa}-$ mine release in vitro by endogenous acetylcholine. Brain Res 248:6169.

Lehmann J, Langer SZ (1983) The striatal cholinergic interneuron: synaptic target of dopaminergic terminals? Neuroscience 10:11051120.

Le Moine C, Bloch B (1991) Rat striatal and mesencephalic neurons contain the long isoform of the $\mathrm{D}_{2}$ dopamine receptor mRNA. Mol Brain Res 10:283-289.

Le Moine C, Normand E, Guitteny AF, Fouque B, Teoule R, Bloch B (1990a) Dopamine receptor gene expression by enkephalin neurons in rat forebrain. Proc Natl Acad Sci USA 87:230-234.

Le Moine C, Tison F, Bloch B (1990b) D2 dopamine receptor gene expression by cholinergic neurons in the rat striatum. Neurosci Let 117:248-252.

Le Moine C, Normand E, Bloch B (1991) Phenotypical characterization of the rat striatal neurons expressing the $D_{1}$ dopamine receptor gene. Proc Natl Acad Sci USA 88:4205-4209.

Levey AI, Kitt CA, Simonds WF, Price DL, Brann MR (1991) Identification and localization of muscarinic acetylcholine receptor proteins in brain with subtype-specific antibodies. J Neurosci 11:32183226.

Lowenstein PR, Joyce JN, Coyle JT, Marshall JF (1990) Striosomal organization of cholinergic $\mathrm{M}_{1}$ receptors in the adult human striatum: a quantitative receptor autoradiographic study. Brain Res 510:122126.

Marchi M, Sanguineti P, Raiteri M (1990) Muscarinic receptors mediate direct inhibition of GABA release from rat striatal nerve terminals. Neurosci Lett 116:347-351.

Morris BJ, Höllt V, Hertz A (1988) Dopaminergic regulation of striatal proenkephalin mRNA and prodynorphin mRNA: contrasting effects of $D_{1}$ and $D_{2}$ antagonists. Neuroscience 25:535-532.

Nastuk MA, Graybiel AM (1985) Patterns of muscarinic cholinergic binding in the striatum and their relation to dopamine islands and striosomes. J Comp Neurol 237:176-194.

Nawa H, Hirose T, Takoshima H, Inayama S, Nakanishi S (1983) Nucleotide sequences of cloned cDNAs for two types of bovine brain substance $P$ precursor. Nature 306:32-36.

Normand E, Bloch B (1991) Simultaneous detection of two messenger RNAs in the central nervous system: a simple two-step in situ hybridization procedure using a combination of radioactive and nonradioactive probes. J Histochem Cytochem 39:1575-1578.

Normand E, Popovici T, Fellmann D, Bloch B (1987) Anatomical study of enkephalin gene expression in the rat forebrain following haloperidol treatment. Neurosci Lett 83:232-236.

Phelps PE, Houser CR, Vaughn JE (1985) Immunocytochemical localization of choline acetyltransferase within the rat neostriatum: a correlated light and electron microscopic study of cholinergic neurons and synapses. J Comp Neurol 238:286-307.

Reiner A, Anderson KD (1990) The pattern of neurotransmitter and neuropeptide co-occurrence among striatal projection neurons: conclusions based on recent findings. Brain Res Rev 15:251-265.

Repke H, Maderspach K (1982) Muscarinic acetylcholine receptors on cultured glia cells. Brain Res 232:206-211.

Richards MH (1991) Pharmacology and second messenger interactions of cloned muscarinic receptors. Biochem Pharmacol 42:16451653.

Rimland J, Xin W, Sweetnam P, Saijoh K, Nestler EJ, Duman RS (1991) Sequence and expression of a neuropeptide $Y$ receptor cDNA. Mol Pharmacol 40:869-875.

Scatton B, Lehmann J (1982) $N$-methyl-D-aspartate type receptor mediates striatal ${ }^{3} \mathrm{H}$-acetylcholine release evoked by excitatory amino acids. Nature 297:422-424.

Schiffmann SN, Jacobs O, Vanderhaegen JJ (1991) Striatal restricted adenosine $A_{2}$ receptor (RDC8) is expressed by enkephalin but not by substance P neurons: an in situ hybridization study. J Neurochem 57: 1062-1067.

Smith Y, Parent A (1986) Neuropeptide Y-immunoreactive neurons in the striatum of cat and monkey: morphological characteristics, intrinsic organization and co-localization with somatostatin. Brain Res 372:241-252.

Spencer DG Jr, Horvath E, Traber J (1986) Direct autoradiographic determination of $M_{1}$ and $M_{2}$ muscarinic acetylcholine receptor distribution in the rat brain: relation to cholinergic nuclei and projections. Brain Res 380:59-68. 
Sugita S, Uchimura N, Jiang ZG, North RA (1991) Distinct muscarinic receptors inhibit release of $\gamma$-aminobutyric acid and excitatory amino acids in mammalian brain. Proc Natl Acad Sci USA 88:2608-2611.

Tang F, Costa E, Schwartz JP (1983) Increase of proenkephalin mRNA content of rat striatum after daily injection of haloperidol for 2 to 3 weeks. Proc Natl Acad Sci USA 80:3841-3844.

Vilaro MT, Wiederhold KH, Palacios JM, Mengod G (1991) Muscarinic cholinergic receptors in the rat caudate-putamen and olfactory tubercle belong predominantly to the $\mathrm{m}_{4}$ class: in situ hybridization and receptor autoradiography evidence. Neuroscience 40:159-167.

Vuillet J, Dimova R, Nieoullon A, Kerkerian-Le Goff L (1992) Ultrastructural relationships between choline acetyltransferase- and neuropeptide $\mathrm{Y}$-containing neurons in the rat striatum. Neuroscience 46 : $351-360$.

Wada E, Wada K, Boulter J, Deneris E, Heinemann S, Patrick J, Swanson LW (1989) Distribution of alpha, alpha ${ }_{3}$, alpha a $_{4}$ and beta neuronal nicotinic receptor subunit mRNAs in the central nervous system: a hybridization histochemical study in the rat. J Comp Neurol 284:314-335

Wainer BH, Bolam JP, Freund TF, Henderson Z, Totterdell S, Smith AD (1984) Cholinergic synapses in the rat brain: a correlated light and electron microscopic immunohistochemical study employing a monoclonal antibody against choline acetyltransferase. Brain Res 308: 69-76.

Weiner DM, Levey AI, Brann MR (1990) Expression of muscarinic acetylcholine and dopamine receptor mRNAs in rat basal ganglia. Proc Natl Acad Sci USA 87:7050-7054.

Yoshikawa K, Williams C, Sabol SL (1984) Rat brain preproenkephalin mRNA:cDNA cloning, primary structure and distribution in the central nervous system. J Biol Chem 259: 14301-14308.

Young WS III, Bonner TI, Brann MR (1986) Mesencephalic dopamine neurons regulate the expression of neuropeptide mRNAs in the rat forebrain. Proc Natl Acad Sci USA 83:9827-9831. 